medRxiv preprint doi: https://doi.org/10.1101/2022.03.03.22271525; this version posted March 5, 2022. The copyright holder for this preprint (which was not certified by peer review) is the author/funder, who has granted medRxiv a license to display the preprint in perpetuity. It is made available under a CC-BY-NC-ND 4.0 International license.

\title{
Features of an aseasonal 2021 RSV epidemic in the UK and Ireland: analysis of the first 10,000 patients
}

Authors: Roland $\mathrm{D}^{1,2}$, Williams $\mathrm{TC}^{3}$, Lyttle MD ${ }^{4,5}$, Marlow $\mathrm{R}^{5}$, Hardelid PC ${ }^{6}$, Sinha $\mathrm{I}^{7,8}$, Swann $\mathrm{OV}^{9}$, Maxwell-Hodkinson $\mathrm{A}^{7}$, Cunningham $\mathrm{S}^{10,11}$ on behalf of the REspiratory Syncytial virus Consortium in EUrope (RESCEU) investigators and the Paediatric Emergency Research United Kingdom and Ireland (PERUKI) Network.

1. Paediatric Emergency Medicine Leicester Academic (PEMLA) Group, Leicester Royal Infirmary, UK

2. Sapphire Group, Health Sciences, Leicester University, University of Leicester, UK

3. Child Life and Health, University of Edinburgh, UK

4. Faculty of Health and Applied Sciences, University of the West of England, UK

5. Emergency Department, Bristol Royal Hospital for Children, Bristol, UK

6. Great Ormond Street Institute of Child Health, University College London, UK

7. University of Liverpool, Liverpool, UK

8. Alder Hey Children's Hospital, Liverpool, UK

9. Centre for Medical Informatics, Usher Institute, University of Edinburgh, UK

10. Department of Paediatric Respiratory and Sleep Medicine, Royal Hospital for Children and Young People, Edinburgh, UK

\section{Corresponding Author:}

Damian Roland

SAPPHIRE Group, Health Sciences, Leicester University, Leicester, UK

Paediatric Emergency Medicine Leicester Academic (PEMLA) Group, Children's Emergency Department, Leicester Royal Infirmary, Leicester, UK

dr98@leicester.ac.uk

\begin{abstract}
BronchStart is a prospective cohort study of infants with clinical bronchiolitis attending Emergency Departments in the United Kingdom and Ireland. We found the 2021 summer lower respiratory tract infection peak, although temporally disrupted and with an attenuated disease burden, predominantly affected younger age groups as in previous years.
\end{abstract}


medRxiv preprint doi: https://doi.org/10.1101/2022.03.03.22271525; this version posted March 5, 2022. The copyright holder for this preprint (which was not certified by peer review) is the author/funder, who has granted medRxiv a license to display the preprint in perpetuity. It is made available under a CC-BY-NC-ND 4.0 International license.

\section{Contributions}

Damian Roland: Conceptualization, Methodology, Project Administration, Writing - Original Draft Preparation, Writing - Review \& Editing

Thomas C. Williams: Conceptualization, Methodology, Writing - Original Draft Preparation, Writing - Review \& Editing

Mark D. Lyttle: Conceptualization, Methodology, Project Administration, Software, Writing Original Draft Preparation, Writing - Review \& Editing

Robin Marlow: Methodology, Data Management

Pia C. Hardelid: Methodology, Writing - Review and Editing

Ian Sinha: Conceptualization, Methodology, Writing - Original Draft Preparation, Writing - Review \& Editing

Olivia V. Swann: Conceptualization, Methodology, Writing - Original Draft Preparation, Writing Review \& Editing

Abigail Maxwell-Hodkinson: Conceptualization, Methodology, Writing - Review \& Editing Steve Cunningham: Conceptualization, Methodology, Project Administration, Writing - Original Draft Preparation, Writing - Review \& Editing

\section{Competing Interests}

No competing interests were disclosed.

\section{Funding Information}

This study received financial and administrative support from the Respiratory Syncytial Virus Consortium in Europe (RESCEU) and Paediatric Emergency Research United Kingdom and Ireland (PERUKI). RESCEU has received funding from the Innovative Medicines Initiative 2 Joint Undertaking under grant agreement No 116019. This Joint Undertaking receives support from the European Union's Horizon 2020 research and innovation programme and EFPIA. The results reported herein reflect only the authors' view, and not of the European commission. As such, the EC is not responsible for any use that may be made of the information contained in this publication.

\section{Acknowledgements}

We thank Khalil Abudahab, Anthony Underwood, and David Aanensen at Microreact for support increating the dashboard, and Linda Wijlaars for assistance in data extraction. We thank Mai Baquedano for technical support in the launch of the REDCap survey tool and ongoing data management, and Darren Goble for information management and technology support, including maintenance of the server and development of a data flow pipeline for the BronchStart outputs. We thank Elizabeth Whittaker for input at the project planning stage. We thank the RESCEU investigators for their support.

\section{Data availability}

Data from the BronchStart Study has been made openly available on a dashboard created by Microreact (https://tinyurl.com/Bronch-Start).

\section{Supplementary material}


medRxiv preprint doi: https://doi.org/10.1101/2022.03.03.22271525; this version posted March 5, 2022. The copyright holder for this preprint (which was not certified by peer review) is the author/funder, who has granted medRxiv a license to display the preprint in perpetuity. It is made available under a CC-BY-NC-ND 4.0 International license .

Supplementary File 1 lists the PERUKI investigators who have been recruiting patients to the BronchStart Study.

\section{Ethics}

This study has been registered with the NIHR (Research Ethics Committee number 21/HRA/1844)and clinicaltrials.gov (Identifier NCT04959734).

Word Count: 673 
medRxiv preprint doi: https://doi.org/10.1101/2022.03.03.22271525; this version posted March 5, 2022. The copyright holder for this preprint (which was not certified by peer review) is the author/funder, who has granted medRxiv a license to display the preprint in perpetuity. It is made available under a CC-BY-NC-ND 4.0 International license.

\section{Main text}

Respiratory syncytial virus (RSV) causes annual winter epidemics that usually peak in December in the UK and Ireland. Infants are disproportionately affected, with infection leading to lower respiratory tract disease, most commonly bronchiolitis, that often result in emergency department visits and hospitalisations. Non-pharmaceutical interventions (NPIs) introduced globally to limit the spread of severe acute respiratory syndrome coronavirus 2 (SARS-CoV-2) led to disruption of the typical RSV seasonality. Australia experienced a delayed RSV peak [1] and a shift in age distribution to older children, with New Zealand reporting more hospital admissions than in previous years [2]. Proposed reasons include larger populations of RSV-naïve infants/children, and decay in transferred maternal RSV IgG antibody. Studies examining the aseasonal resurgence of RSV have been limited by sample size, and lack of information on secondary care episodes and clinical features. The BronchStart study, which commenced in June 2021, is a prospective multi-centre cohort study. Paediatric emergency departments (PED) within PERUKI (Paediatric Emergency Research in the UK and Ireland) submit data on all children under 2 years of age who visit a PED with symptoms of an acute lower respiratory tract infection (diagnosed as bronchiolitis, lower respiratory tract infection, or first episode of acute wheeze), to a secure online Research Electronic Data Capture (REDCap) database. Follow-up information is submitted 7 days later, and study data is made available on a live online dashboard hosted by Microreact [3].

We present initial data for 10,347 infants and children from 44 study sites for the period $1^{\text {st }}$ June to $5^{\text {th }}$ December 2021. The aseasonal 2021 RSV epidemic in the UK has now come to an end, with infections having peaked in August (Figure 1A, [4]). Comparing the age distribution of hospitalised infants $<12$ months to previous years at two large paediatric centres currently participating in the BronchStart Study (Leicester Children's Hospital and Bristol Royal Hospital for Children), we observed a similar age distribution (Figure 1B). This suggests reduced community exposure to RSV during the 15 months preceding the start of the season did not result in a clinically significant lack of protective maternal antibody transfer to those $<3$ months of age, or that the NPIs introduced were not strong enough to prevent low level transmission.

Unlike New Zealand, the overall hospital burden of bronchiolitis in the UK and Ireland in 2021 was lower than previous seasons [4]. Disease severe enough to require intensive care was $2.5 \%$ in our cohort (for those aged 6 weeks to one year), comparable to $4.2 \%$ reported in the BIDS trial [5] (odds ratio using Fisher's exact test 0.59, 95\% confidence interval 0.31-1.18, $p=$ 0.09). We noted a low probability of a SARS-CoV-2-positive RT-PCR test $(83 / 4,328$ children tested,1.9\%; of which 39 were co-infections with another virus) in children presenting with acute lower respiratory tract infection.

We also observed a substantial number of PED visits and admissions for RSV-positive 12-23 month old children in BronchStart: 362 out of 1,468 (24.7\%) admissions were in this age group. This observation of frequent RSV disease in children whose lack of RSV exposure 
medRxiv preprint doi: https://doi.org/10.1101/2022.03.03.22271525; this version posted March 5, 2022. The copyright holder for this preprint (which was not certified by peer review) is the author/funder, who has granted medRxiv a license to display the preprint in perpetuity. It is made available under a CC-BY-NC-ND 4.0 International license.

resulted from the delayed seasonal epidemic, should support future long-term follow-up of children born to mothers who receive RSV vaccination in the future. It is possible that waning immunity after initial protection in the period immediately after birth may expose older children to a more severe first episode of RSV disease.

Here we demonstrate the utility of a large, multi-centre study in rapidly gathering data on novel or disrupted infectious disease transmission dynamics requiring a rapid research response. We found that the 2021 summer lower respiratory tract infection peak in the UK and Ireland, although temporally disrupted and with an attenuated disease burden, predominantly affected younger age groups as in previous years. The overall lower burden of disease in 2021 suggests incomplete infection by RSV of its usual susceptible population, probably due to the effect of ongoing NPIs over the study period, and raises the strong possibility of a further wave of infection in the coming months. We suspect that ourimmunity debt has not yet been fully repaid. 


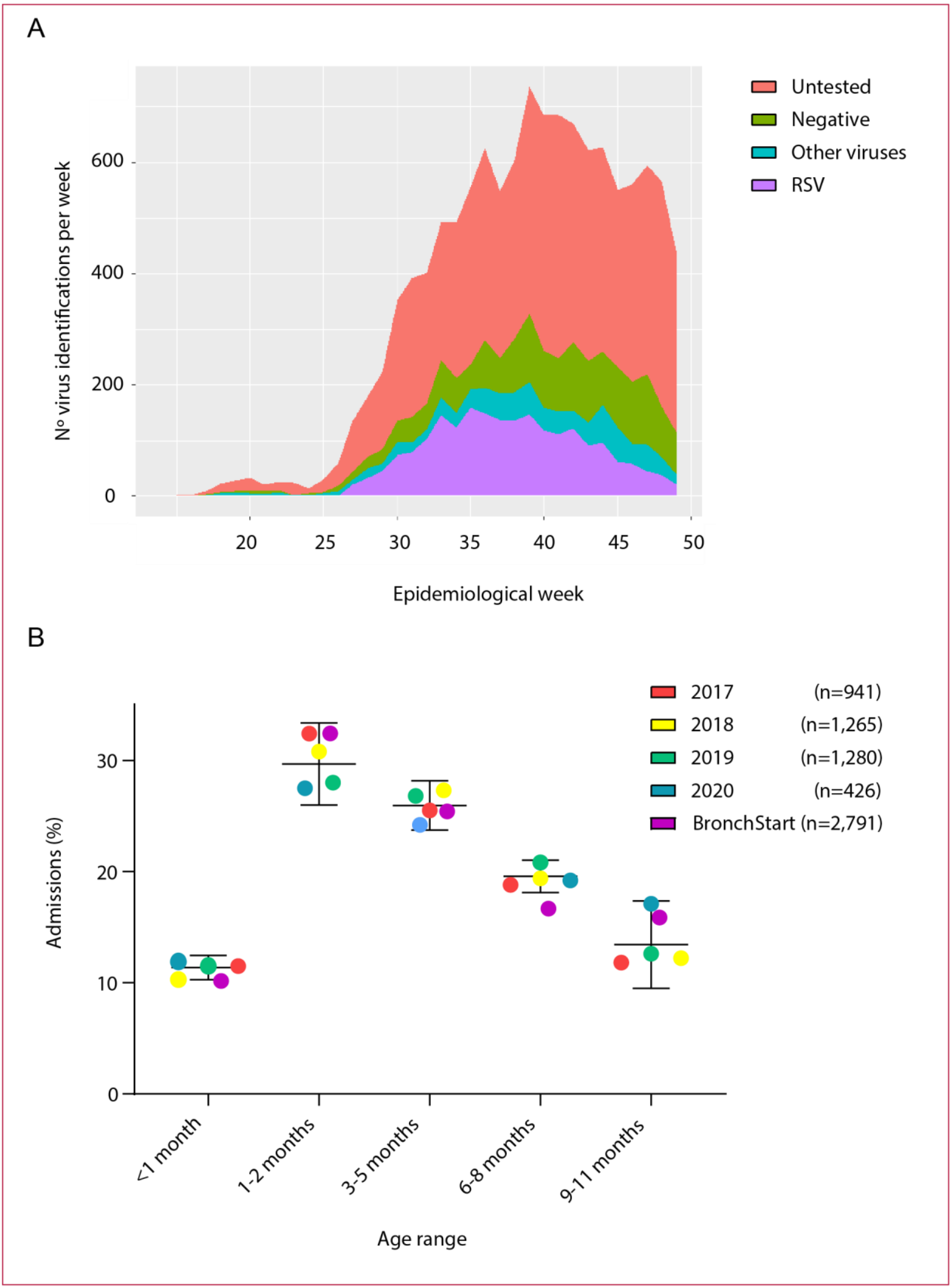

Figure 1: 2021 RSV Season in the United Kingdom and Ireland.

Virus positivity for BronchStart participants (A), showing peak in rates of RSV positivity between epidemiological weeks 30 and 40. Age at admission for previous 2017-2020 at Leicester Children's Hospital and Bristol Royal Hospital for Children compared to BronchStart participants (B). Mean and 95\% confidence intervals for 2017-2020 admissions shown for each age category, together with total number of infants for year. 
medRxiv preprint doi: https://doi.org/10.1101/2022.03.03.22271525; this version posted March 5, 2022. The copyright holder for this preprint (which was not certified by peer review) is the author/funder, who has granted medRxiv a license to display the preprint in perpetuity.

\section{References}

1. Foley DA, Yeoh DK, Minney-Smith CA, Martin AC, Mace AO, Sikazwe CT, Le H, Levy A, Moore HC, Blyth CC. The Interseasonal Resurgence of Respiratory Syncytial Virus in Australian Children Following the Reduction of Coronavirus Disease 2019-Related Public Health Measures. Clin Infect Dis. 2021 Nov 2;73(9):e2829-e2830. doi: 10.1093/cid/ciaa1906. PMID: 33594407; PMCID: PMC7929151.

2. Hatter L, Eathorne A, Hills T, Bruce P, Beasley R. Respiratory syncytial virus: paying the immunity debt with interest. Lancet Child Adolesc Health. 2021 Dec;5(12):e44-e45. doi: 10.1016/S2352-4642(21)00333-3. Epub 2021 Oct 23. PMID: 34695374; PMCID: PMC8598182. 3. BronchStart Dashboard. https://tinyurl.com/Bronch-Start. Website last accessed $12^{\text {th }}$ January 2022.

4. Weekly Hospital Admission Rates of RSV positive cases. United Kingdom Health and Security Agency Joint Modelling Team. Week 51 National Influenza and COVID-19 report. https://assets.publishing.service.gov.uk/government/uploads/system/uploads/attachment da ta/file/1043583/Weekly Flu and COVID-19 report w51.pdf. Website last accessed $3^{\text {rd }}$ January 2022.

5. Cunningham S, Rodriguez A, Adams T, Boyd KA, Butcher I, Enderby B, MacLean M, McCormick J, Paton JY, Wee F, Thomas H, Riding K, Turner SW, Williams C, McIntosh E, Lewis SC; Bronchiolitis of Infancy Discharge Study (BIDS) group. Oxygen saturation targets in infants with bronchiolitis (BIDS): a double-blind, randomised, equivalence trial. Lancet. 2015 Sep 12;386(9998):1041-8. doi: 10.1016/S0140-6736(15)00163-4. PMID: 26382998; PMCID: PMC467309 